\title{
Carotid body physiology meets cytochrome c oxidase crystallography Commentary to Ortega-Sáenz P, López-Barneo J. Physiology of the Carotid Body: From Molecules to Disease. Annu Rev Physiol 82: 127-149, 2020. Torres-Torrelo H, Ortega-Sáenz P, Gao L, López-Barneo J. Lactate sensing mechanisms in arterial chemoreceptor cells. Nat Commun 12: 4166, 2021
}

\author{
Helmut Acker ${ }^{1} \cdot$ Joachim Fandrey $^{1}$ (i) \\ Received: 13 December 2021 / Revised: 13 December 2021 / Accepted: 28 December 2021 / Published online: 4 January 2022 \\ (c) The Author(s) 2022
}

The carotid body $(\mathrm{CB})$ oxygen-sensing mechanism remains elusive. Mitochondrial complex I and complex IV of CB type I cells are the most likely oxygen sensor candidates for initiating the hypoxia-induced release of neurotransmitters (NT) to excite synaptically connected sinus nerve fibers [7]. $\mathrm{CB}$ cytochrome c oxidase $(\mathrm{CBCcO})$ is specialized by the subunit $\mathrm{COX} 4 \mathrm{i} 2[2,7]$ which is characterized by twofold lower oxygen affinity than $\mathrm{COX} 4 \mathrm{i} 1$ [8]. In general, $\mathrm{CcO}$ contains four redox centers: heme a and heme a3 linked by helix-X and two copper centers ( $\mathrm{CuA}$ and $\mathrm{CuB})$. Oxygen binds to the heme $\mathrm{a}_{3}-\mathrm{Cu}_{\mathrm{B}}$ binuclear center as described in crystallographic studies on bovine $\mathrm{CcO}(\mathrm{bCcO})$ microcrystals [3]. When helix-X relaxes, communication between the two heme groups facilitates electron transfer from mitochondrial cytochrome c (complex III) over $\mathrm{CuA}$ to heme a and the binuclear center.

As surrogate for oxygen, $\mathrm{CO}$ and NO replace oxygen at the binuclear center in a light-sensitive way and inhibit electron transfer [3]. Upon light-induced $\mathrm{CO}$ photodissociation under reducing conditions, helix-X switches from the open to the closed state when ferrous heme a3 iron is in an exogenous ligand-free state like in hypoxia [3]. Based on these studies, we present a deeper understanding of the nature of the $\mathrm{CB}$ oxygen sensor by reanalyzing $\mathrm{CO}$ experiments on isolated rat CBs super-fused in vitro as shown in Fig. 1a [4]. Changing gas composition of the super-fusion medium from $20 \% \mathrm{O}_{2}, 3 \% \mathrm{CO}_{2}, 77 \% \mathrm{~N}_{2}$ (normoxia) to $97 \% \mathrm{~N}_{2}, 3 \%$

Joachim Fandrey

joachim.fandrey@uni-due.de

1 Institut Für Physiologie, Universität Duisburg-Essen, Hufelandstr. 55, D-45147 Essen, Germany
$\mathrm{CO}_{2}$ (full hypoxia) is followed by a characteristic hypoxiainduced increased chemoreceptor sinus nerve activity (registration in black) serving as control. Replacing $77 \% \mathrm{~N}_{2}$ by $\mathrm{CO}$ induces an increased sinus nerve activity (registration in red) which is decreased to normoxic control levels by $\mathrm{CO}$ photodissociation and oxygen ligand binding to the binuclear a3-CuB center reestablishing electron transfer. Additional $\mathrm{CO}$ to fully replace $\mathrm{O}_{2}$ (resulting in $97 \% \mathrm{CO}$ and $3 \% \mathrm{CO}_{2}$ ) increases chemoreceptor sinus nerve activity (full hypoxia, registration in red). $\mathrm{CO}$ photo-dissociation is followed by a further increase of chemoreceptor discharge reaching hypoxic control levels. We propose that ferrous heme a3 iron now is in an exogenous ligand-free state and helix-X compressed into a closed conformation with inhibited electron transfer due to increased distance between heme a/a3.

We assume this large helix-X movement of about $3 \AA$ [3] acts as a primary sensor signal to trigger chemoreceptor discharge under hypoxia by inducing a motion of the intracellular mitochondrial network [10] with subsequent cell shape changes (see Fig. 1c). This motion might trigger mechano-sensitive cation membrane channels leading to a primary rise of intracellular calcium initiating NT release.

To further characterize $\mathrm{CBCcO}$, the mean hypoxic light absorption spectrum (black registration) of $\mathrm{CBCcO}$ was recorded (Fig. 1b; [1, 4]). The spectrum was fitted by deconvolution (red line) using characteristic light absorption spectra of mitochondrial cytochromes (c550, b563) and NADPH cytochrome (b558). CBCcO peaks at $592 \mathrm{~nm}$ and $603 \mathrm{~nm}$ matching light absorption spectra of bCcO$\mathrm{CO}$ microcrystals peaking at a593nm (CO-bound) and a604nm (ferrous) [3]. We assume that the $\mathrm{CBCcO}$ double peak results from binding of $\mathrm{NO}$ produced under hypoxia [6]. NO inhibits hypoxic CB chemoreception, while it 

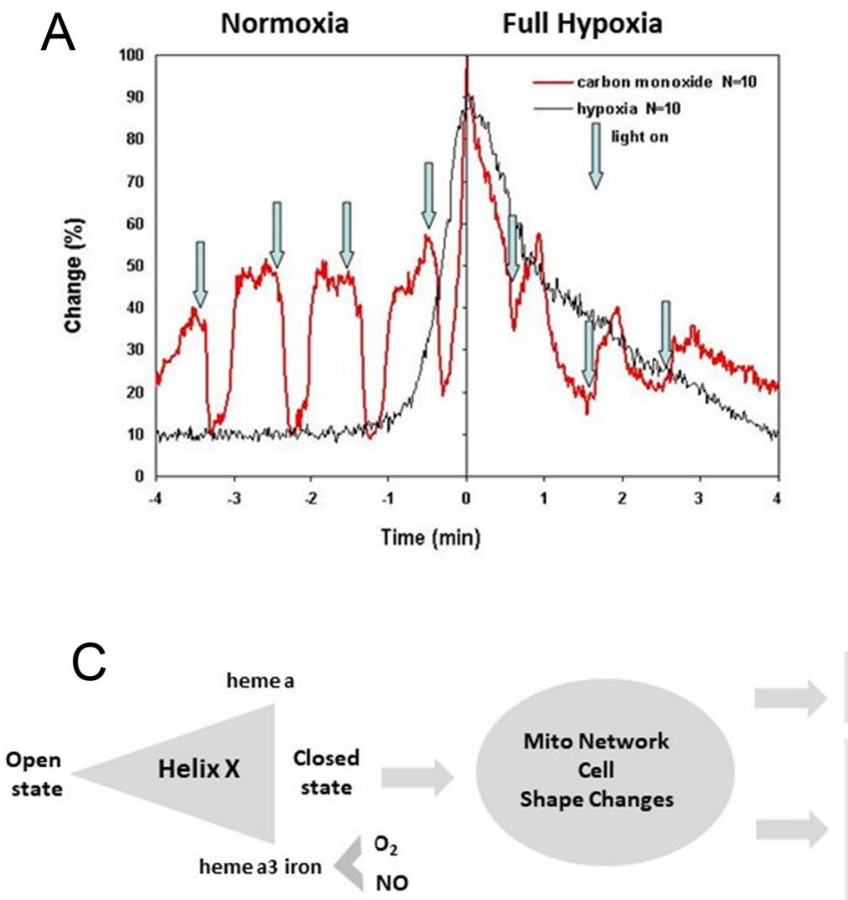

Hypoxia

Fig. $1 \mathrm{CcO}$ crystallographic changes of about 3 Ångström are displayed by $\mathrm{CB}$ chemoreceptor discharge. a Chemoreceptor discharge under normoxic and hypoxic $\mathrm{CO}$ application (red registration line) The effect of $\mathrm{CO}$ is shown as a percentage of peak chemoreceptor activity induced by 4-min hypoxia. Control chemoreceptor discharge without $\mathrm{CO}$ is shown as the black line. Data are mean values from 10 carotid bodies. CO application during normoxia (left side at time-4) leads to excitation, which is eliminated during lightinduced photodissociation (vertical arrows). CO application during full hypoxia (right side of time zero) leads to discharge inhibition, which is reversed during photodissociation [4]. b Identification of carotid body heme proteins by light absorption photometry. $\mathrm{N}_{2}$ versus aerobic steady-state spectrum (black solid noisy line; mean values of 6 carotid bodies) was fitted by different mitochondrial and non-mito-

\section{B}

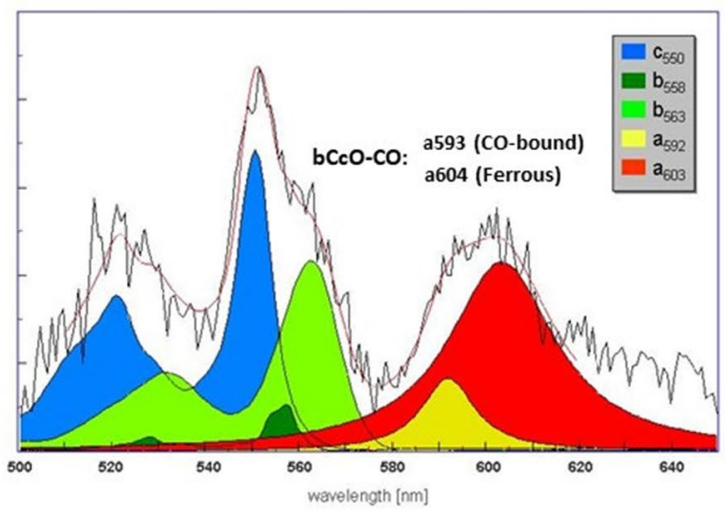

chondrial cytochrome spectra as indicated by different colors. The deconvolution fit curve (red solid line) obtained by varying the amplitude of the optical density of five cytochromes closely fits the experimental curve [1]. $\mathrm{CBCcO}$ double-absorption peaks are assumed to be comparable to bCcO $\mathrm{CO}$ bound and ferrous absorption peaks. c Changes in Helix- $\mathrm{X}$ from open to closed state under hypoxia are finetuned by interaction of $\mathrm{O}_{2}$ and NO binding on heme a3 iron. Subsequent mitochondria-induced cell shape changes lead to intracellular calcium increase and NT release (primary pathway). Reduced electron transfer between heme a and heme a3 stimulates aerobic glycolysis with subsequent lactate production. Subsequent tissue acidification inactivates TASK channels. In addition, ROS affecting the redox status involving PIN1/p47 $7_{\text {phox }}$ interact with TASK channels (amplification pathway) [2] increases the chemosensory discharges in normoxia [6]. Upon binding to $\mathrm{CBCcO}$, NO seems to induce the same helix-X changes like $\mathrm{CO}$. NO ligand binding to $\mathrm{CBCcO}$ is reported to decrease oxygen consumption and favoring aerobic glycolysis [2]. Subsequent tissue acidification and lactate production as shown in Fig. 1c could lead to amplification of the primary calcium signal by closing TASK channels involving the PIN1/p47 $7_{\text {phox }}$ tandem [2] and influencing the $\mathrm{Fp} /(\mathrm{Fp}+\mathrm{NAD}(\mathrm{P}) \mathrm{H})$ redox ratio $[2,5,9]$.
Funding Open Access funding enabled and organized by Projekt DEAL.

\section{Declarations}

Conflict of interest The authors declare no competing interests.

Open Access This article is licensed under a Creative Commons Attribution 4.0 International License, which permits use, sharing, adaptation, distribution and reproduction in any medium or format, as long as you give appropriate credit to the original author(s) and the source, provide a link to the Creative Commons licence, and indicate if changes were made. The images or other third party material in this article are 
included in the article's Creative Commons licence, unless indicated otherwise in a credit line to the material. If material is not included in the article's Creative Commons licence and your intended use is not permitted by statutory regulation or exceeds the permitted use, you will need to obtain permission directly from the copyright holder. To view a copy of this licence, visit http://creativecommons.org/licenses/by/4.0/.

\section{References}

1. Acker $H$ (2005) The oxygen sensing signal cascade under the influence of reactive oxygen species. Philos Trans R Soc Lond B Biol Sci 360:2201-2210

2. Bernardini A, Wolf A, Brockmeier U, Riffkin H, Metzen E, Acker-Palmer A, Fandrey J, Acker H (2020) Carotid body type I cells engage flavoprotein and Pin1 for oxygen sensing. Am J Physiol Cell Physiol 318:C719-C731

3. Ishigami I, Zatsepin NA, Hikita M, Conrad CE, Nelson G, Coe JD, Basu S, Grant TD, Seaberg MH, Sierra RG, Hunter MS, Fromme P, Fromme R, Yeh SR, Rousseau DL (2017) Crystal structure of CO-bound cytochrome c oxidase determined by serial femtosecond X-ray crystallography at room temperature. Proc Natl Acad Sci USA 114:8011-8016

4. Lahiri S, Ehleben W, Acker H (1999) Chemoreceptor discharges and cytochrome redox changes of the rat carotid body: role of heme ligands. Proc Natl Acad Sci USA 96:9427-9432
5. Li LZ, Xu HN, Ranji M, Nioka S (2009) Mitochondrial redox imaging for cancer diagnostic and therapeutic studies. J Innov Opt Heal Sci 2:325-341

6. Moya EA, Alcayaga J, Iturriaga R (2012) NO modulation of carotid body chemoreception in health and disease. Respir Physiol Neurobiol 184:158-164

7. Ortega-Sáenz P, López-Barneo J (2020) Physiology of the carotid body: from molecules to disease. Annu Rev Physiol 82:127-149

8. Pajuelo Reguera D, Čunátová K, Vrbacký M, Pecinová A, Houštěk J, Mráček T, Pecina P (2020) Cytochrome c oxidase subunit 4 isoform exchange results in modulation of oxygen affinity. Cells 9:443

9. Torres-Torrelo H, Ortega-Sáenz P, Gao L, López-Barneo J (2021) Lactate sensing mechanisms in arterial chemoreceptor cells. Nat Commun 12:4166

10. Zamponi N, Zamponi E, Cannas SA, Billoni OV, Helguera PR (2018) Mitochondrial network complexity emerges from fission/ fusion dynamics. Sci Rep 8(1):10

Publisher's note Springer Nature remains neutral with regard to jurisdictional claims in published maps and institutional affiliations. 